$\xi=$

\title{
Seasonal Diversity of Butterflies in the Fragmented Habitats of Waghai Botanical Garden of The Dangs - Gujarat
}

\author{
Suchi Gandhi, Dolly Kumar * \\ Division of Entomology, Department of Zoology, Faculty of Science, The Maharaja Sayajirao University of Baroda, \\ Vadodara-390002, Gujarat, India \\ *Corresponding author E-mail: dollymsu@gmail.com
}

\begin{abstract}
Background: The world is currently undergoing a very rapid loss of butterfly biodiversity comparable with the great mass extinction events that have previously occurred only five or six times in the Earth's history. This is an alarming call of these tiny scraps of biodiversity which now have scarce appearance surrounding the huge human kingdom.

Objective: The richness of biodiversity depends on the climatic conditions and area of the region. The present research work focuses on studying butterflies diversity, their habitat preferences and seasonal distribution in structured plots of Waghai Botanical Garden.

Method: For carrying out systematic study, Waghai Botanical Garden was fragmented into five sub habitats i.e. Dry \& Moist Deciduous plot, Evergreen plot, Bamboo plot \& Dang plot, Scrub Thorn Forest \& Medicinal \& Taxonomy plot. Intra-individual comparative abundance study for observed butterfly species within fragmented plots of Waghai botanical garden was carried out graphically to study the butterfly's preference in the plots of botanical garden.

Results: Out of 70 species, the maximum number of species i.e. 27 species were observed from family Nymphalidae, followed by 18 species from Lycaenidae, 15 species from Pieridae, Papilionidae with 7 species and 3 species from Hesperiidae.

Conclusion: During post-monsoon season, highest total average rainfall of around $850 \mathrm{~mm}$ was observed in Waghai during monsoon, which provided excellent quality and quantity of larval food plants for the caterpillars and nectar rich flower source for adult butterflies in post-monsoon months. Thus maximum numbers of butterflies' species were observed during the months of October \& November.
\end{abstract}

Keywords: Butterflies; Botanical Garden; Gujarat; Habitat Preference; Seasonal Diversity.

\section{Introduction}

The diversity of life is one of the most striking aspects of our planet; hence knowing how many species inhabit. Earth is among the most fundamental questions in science (Mora et al., 2011). Today, there is an urgent need of not only the in-depth research on diversity but also to induce it for conservation. Diversity studies leads to the destined path of conservation. Biodiversity is the variety of different types of life found on the Earth and the variations within species. It is a measure of the variety of organisms present in different ecosystems.

The richness of biodiversity depends on the climatic conditions and area of the region. Waghai is about $32 \mathrm{~km}$ north from the district headquarters of Ahwa, and about $52 \mathrm{~km}$ south of the hill station of Saputara in the Dangs district. Also known as the Cherarapunji of the state, average rainfall of $2000 \mathrm{~mm}$, which is spread over 90 days makes Dang a paradise. With lush green forest, bamboo breaks and waterfall, the entire hilly terrain of Dangs harbour an amazing variety of plants, butterflies and birds. Temperature varies from minimum of $10^{\circ} \mathrm{C}$ in January to maximum of $36^{\circ} \mathrm{C}$ in June. The Dangs forest tract falls between the parallels of latitude $20.33^{\prime} 53^{\prime \prime}$ and $21.3^{\prime} 52^{\prime \prime}$ and the meridians of longitude $73.27 ' 58^{\prime \prime}$ and 73.56'36". The Dangs forest tract starts from the rugged mountain chains of Sahyadri in the east and descends on the western side extending to the edge of plains of Gujarat. The hills are mostly low and flat topped. In the Dangs, Waghai Botanical Garden is a large (24-hectare) garden with 1,400 varieties of plants from all over India. The amateur nature lover can marvel at different varieties of bamboo like the Chinese Bamboo, Golden Bamboo, Beer Bottle Bamboo, etc. and enjoy strolling along the beautiful walkways each lined with different species of tree.

General lepidopteran studies have already been carried out in $\mathrm{Gu}$ jarat with respect to protected areas (Aldrich 1946, Mosse 1929, Shull 1964) and wildlife sanctuaries (Sharma \& Ahmed 2013, Bhalodia et al. 2002) and fragmented habitats of urban residential \& agriculture landscapes (Mali et al. 2014, Gandhi \& Kumar 2015). But no work has been focused on fragmented habitats like botanical garden. Apart from that, earlier lepidopteran diversity studies were least combined with their seasonal occurrence or their habitat preferences. Thus, the present research work focuses on studying rhopalocerans, their habitat preferences and seasonal distribution in selected fragmented plots of Waghai Botanical Garden at Gujarat, India. 

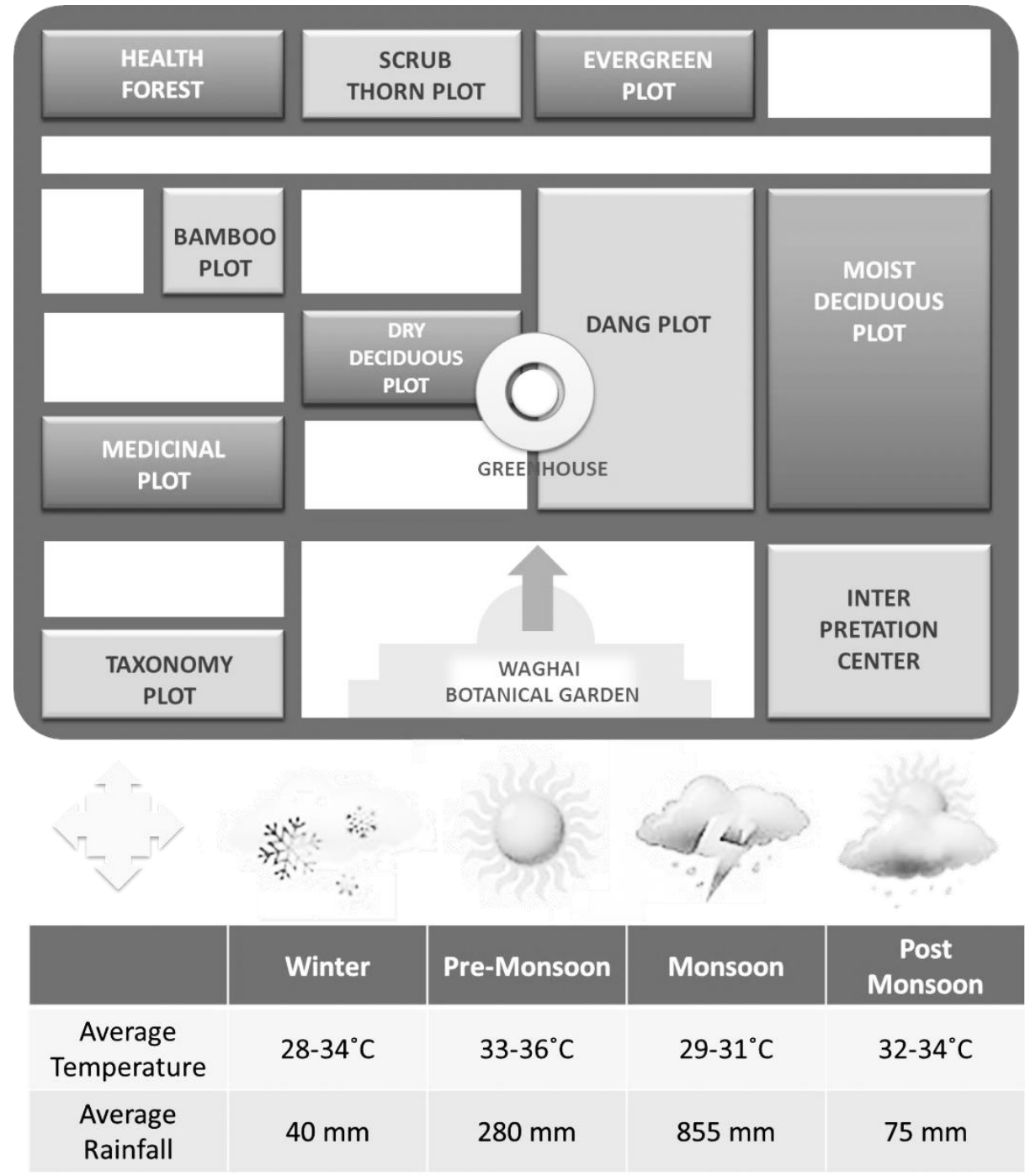

Fig. 1: Schematic Representation of Waghai Botanical Garden with Associated Seasonal Factors

\section{Materials \& methods}

\subsection{Sampling Protocol - Pollard Walk method}

Systematic approach was followed to monitor the rhopalocerans During the entire study of three consecutive years from 2012 to 2015, Pollard Walk method was utilized to document the butterflies though with modification (Pollard \& Yates 1993). Pollard Walk method states that each fixed path is walked along a fixed duration time. In the present study, selected path visits were made during the morning time i.e. 900-1200 hours and later at 15001800 hours.

Each path is walked upon for a period of 2-3 hours and the visibility of 10 meters was kept at both the sides of the path as represented in scheme of Waghai Botanical Garden in Figure 1. Visual encounters were made during the entire study period. Rhopaloceran collection was made whenever butterflies were unidentified on field sessions. Butterflies were observed on both the sides of the paths within botanical garden.

\subsection{Collection of Data}

Studies on rhopaloceran diversity was conducted from 2012 to 2015, i.e for a period of three years. Utilizing the Pollard Walk Method, required observations were made in the morning \& evening hours. Majority of the rhopalocerans were identified characteristically on the field using standard references.
On- field essentials were carried during all the field visits. This includes well-featured camera, butterfly net, storage vials and identification keys (picture guides). Visual observations and butterfly net method was used to monitor and identify butterflies. Butterflies were identified on the field site itself and if not identified were collected using butterfly net. Adult butterflies were usually collected with the help of butterfly net (Kunte, 2000). Depending on the number of sightings, abundance of butterfly species were categorised into Very Common ( $>25$ sightings during the entire study period), Common (10-25 sightings) and Rare (1-5 sightings).

\subsection{Rendering Habitat Preference}

Table 1: Sub- Habitats of Waghai Botanical Garden in The Dangs

\begin{tabular}{|c|c|c|}
\hline $\begin{array}{l}\mathrm{Sr} \\
\mathrm{No}\end{array}$ & $\begin{array}{l}\text { Fragmented } \\
\text { Habitat }\end{array}$ & Description of Zone \\
\hline 1 & $\begin{array}{l}\text { Dry \& Moist } \\
\text { Deciduous Plot }\end{array}$ & $\begin{array}{l}\text { Dry \& Moist tree or shrub species shedding its } \\
\text { leaves annually }\end{array}$ \\
\hline 2 & $\begin{array}{l}\text { Evergreen } \\
\text { Plot }\end{array}$ & $\begin{array}{l}\text { Plants retaining green leaves through } \\
\text { out the year }\end{array}$ \\
\hline 3 & $\begin{array}{l}\text { Bamboo \& Dang } \\
\text { Plot }\end{array}$ & $\begin{array}{l}\text { A plot having giant woody grass which is } \\
\text { grown chiefly in the tropics. }\end{array}$ \\
\hline 4 & $\begin{array}{l}\text { Scrub Thorn } \\
\text { Forest }\end{array}$ & $\begin{array}{l}\text { Consists primarily of small, tall, thorny trees } \\
\text { that shed their leaves seasonally }\end{array}$ \\
\hline 5 & $\begin{array}{l}\text { Medicinal\& } \\
\text { Taxonomy Plot }\end{array}$ & $\begin{array}{l}\text { General \& Specific systemic arrangement of } \\
\text { trees and plants }\end{array}$ \\
\hline
\end{tabular}


Waghai botanical garden of the Dangs was selected as a model fragmented habitat to study the abundance of butterfly species in botanical garden. For carrying out organized study, Waghai Botanical Garden was fragmented into five sub habitats as mentioned in Table 1 .i.e. (i) Dry \& Moist Deciduous plot, (ii) Evergreen plot, (iii) Bamboo plot \& Dang plot, (iv) Scrub Thorn Forest \& (v) Medicinal \& Taxonomy plot. Dry tree or shrub shedding its leaves annually forms Dry Deciduous Plot \& Moist tree or shrub shedding its leaves annually forms Moist Deciduous Plot; while plants retaining green leaves throughout the year forms the evergreen plot. Bamboo \& Dang plot covers giant woody grass which is grown chiefly in the tropics. Scrub Thorn Forest consists primarily of small, tall, thorny trees that shed their leaves seasonally. Medicinal \& Taxonomy Plot comprises of general \& specific systemic arrangement of trees and plants which are medically important. Intra-individual comparative abundance study for observed butterfly species within fragmented plots of Waghai botanical garden was carried out graphically to study the butterfly's preference for the fragmented habitats of botanical garden.

\subsection{Rendering Seasonal Variations}

Table 2: Climatological Seasons of India with respect to months

\begin{tabular}{|c|c|c|}
\hline $\begin{array}{l}\mathrm{Sr} \\
\mathrm{No}\end{array}$ & Climatological Season & Months \\
\hline 1 & Winter & $\begin{array}{l}\text { December, January, } \\
\text { February, March }\end{array}$ \\
\hline 2 & Pre Monsoon (Summer) & April, May, June \\
\hline 3 & Monsoon (Rainy) & July, August, September \\
\hline 4 & Post Monsoon (Autumn) & October, November \\
\hline
\end{tabular}

To study the effect of different seasons on the diversity of butterflies, seasonal monthly visits were made to the selected fragmented habitats of Waghai Botanical Garden. The months were divided into winter, pre-monsoon, monsoon and post monsoon seasons as depicted in Table 2. December, January, February and March forms winter season, the months April, May and June are considered as the pre-monsoon months; whereas July, August and September months form the monsoon season. October and November form the post monsoon season.

During the visit to the selected fragmented habitats, the maximum temperature and rainfall data was obtained. Hence, the average maximum temperature and average monthly rainfall details of three years i.e. from $2012-2015$ were utilized for monthly comparative study with respect to the observed number of butterfly species.

\subsection{Photographing Butterflies}

One of the most pleasant aspects of studying butterflies is capturing them digitally garnishing with some patience. Rhopaloceran photography was done using Sony Cybershot DSC- W220 with 12.1 megapixels and 4X optical zoom.

Along with that, Lumix Panasonic DMC-FZ 60 with 16.1 megapixels and 24X Optical Zoom was also utilized for photographing small sized butterflies. Required editing of photographs was done using essential softwares.

\subsection{Taxonomical Identification of Rhopalocerans}

Taxonomic identification of the rhopalocerans using the multiple pictorial field guides as on-field identification manuals and standard reference books for their systematic identification. Pictorial guides of (Kunte, 2000), (Kehimkar, 2008) and (Parasharya \& Jani, 2007) were helpful during field visits. Standard works of (Evans, 1932) and (Wynter Blyth, 1957) were utilized to confirm the on field identification. Expert advice was taken as and when required for the confirm identification of species.

Concerned identification of host plants or nectar resources was done by the faculty members of Department of Botany, Faculty of Science, The Maharaja Sayajirao University of Baroda, Vadodara.

\subsection{Statistical Analysis of Species Diversity}

Alpha diversity indices were utilized to analyse the butterfly diversity using the statistical software PAST version $2.17 \mathrm{c}$ :

Shannon Weiner Diversity Index: This typical diversity index states the number of species within site with the relative abundance of each species.

It is defined as:

$\mathrm{H}^{\prime}=\Sigma$ pi ln pi (where $\mathrm{pi}=$ proportion of the $\mathrm{i}^{\text {th }}$ species in the total sample)

Pielou's Evenness Index: This index states the distribution of the relative abundance of species in a site.

It is defined as:

$\mathrm{J}=\mathrm{H}^{\prime} / \ln \mathrm{S}$ (where $\mathrm{S}=$ number of species present in the site)

The value of $\mathrm{J}$ ranges from 0 to 1 . Less is the variation in communities between the species, the higher the value of $\mathrm{J}$.

\section{Results \& Discussion}

A total of 70 butterflies species belonging to 5 families and 49 genera were observed during the entire study period. Of which, maximum number of species were observed from family Nymphalidae i.e. 27 species, followed by 18 species from family Lycaenidae, followed by 15 species from family Pieridae, followed by 7 species of family Papilionidae and 3 species belonging to family Hesperiidae as represented in Table 4. Some of the captured photographs of some documented butterfly species in Waghai Botanical Garden were collectively represented in Figure 3.

\subsection{Rendering Sub-habitat Preference}

Table 3: Habitat Preference of Documented Species of Butterflies in SubHabitats of Botanical Garden - Waghai Botanical Garden in The Dangs District, Gujarat, India

\begin{tabular}{llc}
\hline Sr. & Area & $\begin{array}{c}\text { No. of } \\
\text { No }\end{array}$ \\
\hline 1 & Dry \& Moist Deciduous Plot & Butterfly \\
2 & Evecies observed \\
\hline & Dang \& Bamboo Plot & 32 \\
4 & Scrub Thorn \& Health Forest & 19 \\
5 & Medicinal \& Taxonomy Plot & 13 \\
\hline
\end{tabular}

Waghai Botanical Garden comprises of multiple plots like dry and moist deciduous plots, evergreen plot, Dang and Bamboo Plot, Scrub thorn and health forest, Medicinal and taxonomy plot. Medicinal and taxonomy plot showed the maximum number of species i.e. 44 species, followed by evergreen plot with 32 butterfly species, followed by dry and moist deciduous plots with 27 butterfly species. Total 19 butterfly species were observed from Dang and Bamboo plot whereas 13 species was observed from scrub thorn and health forest (Table 3). Graphical comparison between numbers of butterfly species observed is depicted from Figure 2.

As compared to other plots, highest numbers of butterfly species i.e. 44 were found in the systematically developed Medicinal \& Taxonomy plot, due to availability of systematically developed plots having significant number of nectar rich sources \& larval food source plants.

Considerable numbers of butterfly species were found in the dry \& moist deciduous plots of botanical garden due to availability of considerable number of larval food source plants which shed their leaves annually \& in the evergreen plots which remains evergreen forever. Due to lack of nectar rich flower source plants in the tall woody bamboo plots \& Scrub thorn forest, least numbers of butterfly species were observed among all other fragments.

Botanical garden is devoid of any anthropological interference i.e. pesticide or weedicides application. Hence, keeping it at its nature's purity, such habitats harbor good butterfly diversity. 
Diversity indices were calculated to study the species diversity in the Waghai botanical garden. Within Waghai Botanical Garden, Shannon Weiner Diversity \& Pielou's Evenness Index were found to be $3.99 \& 0.77$ respectively.
Typical Shannon Weiner Diversity values are generally between 1.5 and 3.5 in most ecological studies, and the index is rarely greater than 4 . The Shannon index increases as both the richness and the evenness of the habitat increase.

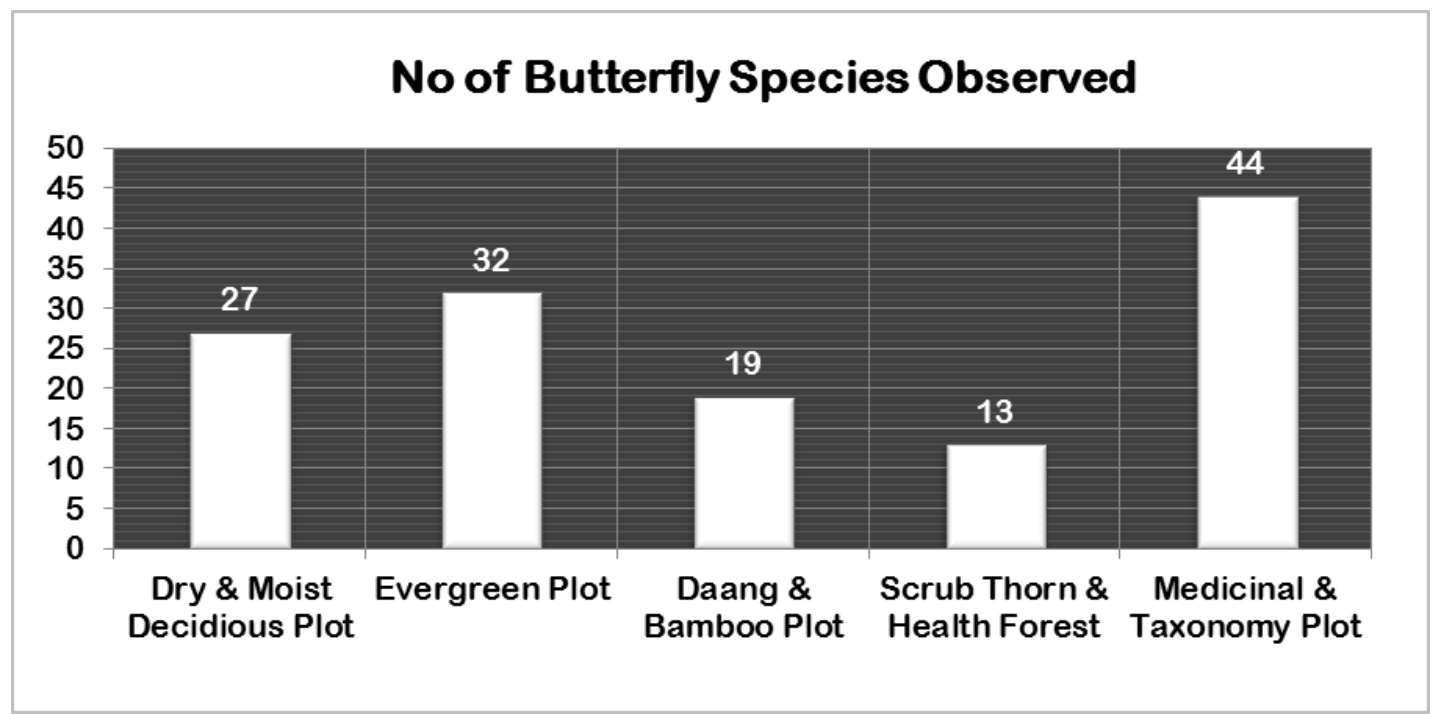

Fig. 2: Habitat Preference of Documented Species of Butterflies in Sub- Habitats of Botanical Garden - Waghai Botanical Garden in The Dangs

Table 4: Butterfly Species Abundance in Waghai Botanical Garden in the Dangs District ( $\mathrm{VC}=$ Very Common, $\mathrm{C}=\mathrm{Common}, \mathrm{R}=\mathrm{Rare}$ )

\begin{tabular}{|c|c|c|c|}
\hline Sr.no & Common name & Scientific Name & Abundance \\
\hline \multicolumn{4}{|c|}{ Family Papilionidae } \\
\hline 1 & Tailed Jay & Graphium agamemnon Linnaeus, 1758 & $\mathrm{VC}$ \\
\hline 2 & Common Jay & Graphium doson Felder \& Felder, 1864 & $\mathrm{VC}$ \\
\hline 3 & Spot Swordtail & Graphium nomius Esper, 1785 & $\mathrm{C}$ \\
\hline 4 & Common Rose & Pachliopta aristolochiae Fabricius, 1775 & $\mathrm{C}$ \\
\hline 5 & Crimson Rose & Pachliopta hector Linnaeus, 1758 & $\mathrm{C}$ \\
\hline 6 & Lime Butterfly & Papilio demoleus Linnaeus, 1758 & $\mathrm{VC}$ \\
\hline 7 & Common Mormon & Papilio polytes Linnaeus, 1758 & $\mathrm{C}$ \\
\hline \multicolumn{4}{|c|}{ Family Pieridae } \\
\hline 8 & Western Striped Albatross & Appias libythea Fabricius, 1775 & $\mathrm{R}$ \\
\hline 9 & Pioneer & Belenois aurota Fabricius, 1793 & $\mathrm{C}$ \\
\hline 10 & Common Emigrant & Catopsilia pomona Fabricius, 1775 & $\mathrm{C}$ \\
\hline 11 & Mottled Emigrant & Catopsilia pyranthe Linnaeus, 1758 & $\mathrm{C}$ \\
\hline 12 & Common Gull & Cepora nerissa Fabricius, 1775 & $\mathrm{C}$ \\
\hline 13 & Small Salmon Arab & Colotis amata Fabricius, 1775 & $\mathrm{R}$ \\
\hline 14 & Crimson Tip & Colotis danae Fabricius, 1775 & $\mathrm{C}$ \\
\hline 15 & Small Orange Tip & Colotis etrida Boisduval, 1836 & $\mathrm{C}$ \\
\hline 16 & Common Jezebel & Delias eucharis Drury, 1773 & $\mathrm{C}$ \\
\hline 17 & Small Grass Yellow & Eurema brigitta Stoll, 1780 & $\mathrm{VC}$ \\
\hline 18 & Common Grass Yellow & Eurema hecabe Linnaeus, 1758 & $\mathrm{VC}$ \\
\hline 19 & White Orange Tip & Ixias marianne Cramer, 1779 & $\mathrm{C}$ \\
\hline 20 & Yellow Orange Tip & Ixias pyrene Linnaeus, 1764 & $\mathrm{C}$ \\
\hline 21 & Psyche & Leptosia nina Fabricius, 1793 & $\mathrm{C}$ \\
\hline 22 & Common Wanderer & Pareronia hippia Fabricius, 1787 & $\mathrm{R}$ \\
\hline \multicolumn{4}{|c|}{ Family Nymphalidae } \\
\hline 23 & Tawny Coster & Acraea terpsicore Linnaeus, 1758 & $\mathrm{C}$ \\
\hline 24 & Angled Castor & Ariadne ariadne Linnaeus, 1763 & $\mathrm{R}$ \\
\hline 25 & Common Castor & Ariadne merione Cramer, 1777 & $\mathrm{C}$ \\
\hline 26 & Common Nawab & Charaxes athamas Drury, 1770 & $\mathrm{R}$ \\
\hline 27 & Black Rajah & Charaxes solon Fabricius, 1793 & $\mathrm{R}$ \\
\hline 28 & Painted Lady & Vanessa cardui Linnaeus, 1758 & $\mathrm{R}$ \\
\hline 29 & Plain Tiger & Danaus chrysippus Linnaeus, 1758 & $\mathrm{VC}$ \\
\hline 30 & Striped Tiger & Danaus genutia Cramer, 1779 & $\mathrm{VC}$ \\
\hline 31 & Common Indian Crow & Euploea core Cramer, 1780 & $\mathrm{VC}$ \\
\hline 32 & Common Baron & Euthalia aconthea Cramer, 1777 & $\mathrm{R}$ \\
\hline 33 & Great Eggfly & Hypolimnas bolina Linnaeus, 1758 & $\mathrm{C}$ \\
\hline 34 & Danaid Eggfly & Hypolimnas misippus Linnaeus, 1764 & $\mathrm{C}$ \\
\hline 35 & Peacock Pansy & Junonia almana Linnaeus, 1758 & $\mathrm{C}$ \\
\hline 36 & Grey Pansy & Junonia atlites Linnaeus, 1763 & $\mathrm{C}$ \\
\hline 37 & Yellow Pansy & Junonia hierta Fabricius, 1798 & $\mathrm{C}$ \\
\hline 38 & Chocolate Pansy & Junonia iphita Cramer, 1779 & $\mathrm{C}$ \\
\hline 39 & Lemon Pansy & Junonia lemonias Linnaeus, 1758 & $\mathrm{VC}$ \\
\hline 40 & Blue Pansy & Junonia orithya Linnaeus, 1758 & $\mathrm{C}$ \\
\hline 41 & Common Evening Brown & Melanitis leda Linnaeus, 1758 & $\mathrm{VC}$ \\
\hline 42 & Common Bushbrown & Mycalesis perseus Fabricius, 1775 & $\mathrm{VC}$ \\
\hline 43 & Common Sailer & Neptis hylas Linnaeus, 1758 & $\mathrm{C}$ \\
\hline 44 & Glassy Tiger & Parantica aglea Stoll, 1782 & $\mathrm{VC}$ \\
\hline 45 & Common Leopard & Phalanta phalantha Drury, 1773 & $\mathrm{C}$ \\
\hline
\end{tabular}




\begin{tabular}{|c|c|c|c|}
\hline Sr.no & Common name & Scientific Name & Abundance \\
\hline 46 & Baronet & Symphaedra nais Forster, 1771 & $\mathrm{C}$ \\
\hline 47 & Blue Tiger & Tirumala limniace Cramer, 1775 & VC \\
\hline 48 & Common Five-ring & Ypthima baldus Fabricius, 1775 & $\mathrm{C}$ \\
\hline 49 & Common Four-ring & Ypthima huebneri Kirby, 1871 & $\mathrm{C}$ \\
\hline \multicolumn{4}{|c|}{ Family Lycaenidae } \\
\hline 50 & Plum Judy & Abisara echerius Stoll, 1790 & $\mathrm{R}$ \\
\hline 51 & Angled Pierrot & Caleta decidia Hewitson, 1876 & $\mathrm{C}$ \\
\hline 52 & Common Pierrot & Castalius rosimon Fabricius, 1775 & $\mathrm{C}$ \\
\hline 53 & Forget-Me-Not & Catochrysops strabo Fabricius, 1793 & $\mathrm{C}$ \\
\hline 54 & Lime Blue & Chilades lajus Stoll, 1780 & $\mathrm{C}$ \\
\hline 55 & Plains Cupid & Chilades pandava Horsfield, 1829 & $\mathrm{C}$ \\
\hline 56 & Angled Sunbeam & Curetis dentate Moore, 1879 & $\mathrm{R}$ \\
\hline 57 & Indian Sunbeam & Curetis thetis Drury, 1773 & $\mathrm{C}$ \\
\hline 58 & Gram Blue & Euchrysops cnejus Fabricius, 1798 & $\mathrm{C}$ \\
\hline 59 & Indian Cupid & Everes lacturnus Godart, 1824 & $\mathrm{C}$ \\
\hline 60 & Common Cerulean & Jamides celeno Cramer, 1775 & $\mathrm{R}$ \\
\hline 61 & Zebra Blue & Leptotes plinius Fabricius, 1793 & $\mathrm{C}$ \\
\hline 62 & Pale Grass Blue & Pseudozizeeria maha Kollar, 1848 & $\mathrm{C}$ \\
\hline 63 & Red Pierrot & Talicada nyseus Guerin- Meneville, 1843 & $\mathrm{C}$ \\
\hline 64 & Stripped Pierrot & Tarucus nara Kollar, 1848 & $\mathrm{C}$ \\
\hline 65 & Dark Grass Blue & Zizeeria karsandra Moore, 1865 & $\mathrm{C}$ \\
\hline 66 & Lesser Grass Blue & Zizina otis Fabricius, 1787 & $\mathrm{C}$ \\
\hline 67 & Tiny Grass Blue & Zizula hylax Fabricius, 1775 & $\mathrm{C}$ \\
\hline \multicolumn{4}{|c|}{ Family Hesperiidae } \\
\hline 68 & Brown Awl & Badamia exclamationis Fabricius, 1775 & $\mathrm{R}$ \\
\hline 69 & Rice Swift & Borbo cinnara Wallace, 1866 & $\mathrm{R}$ \\
\hline 70 & Dark Palm Dart & Telicota bambusae Moore, 1878 & $\mathrm{R}$ \\
\hline
\end{tabular}
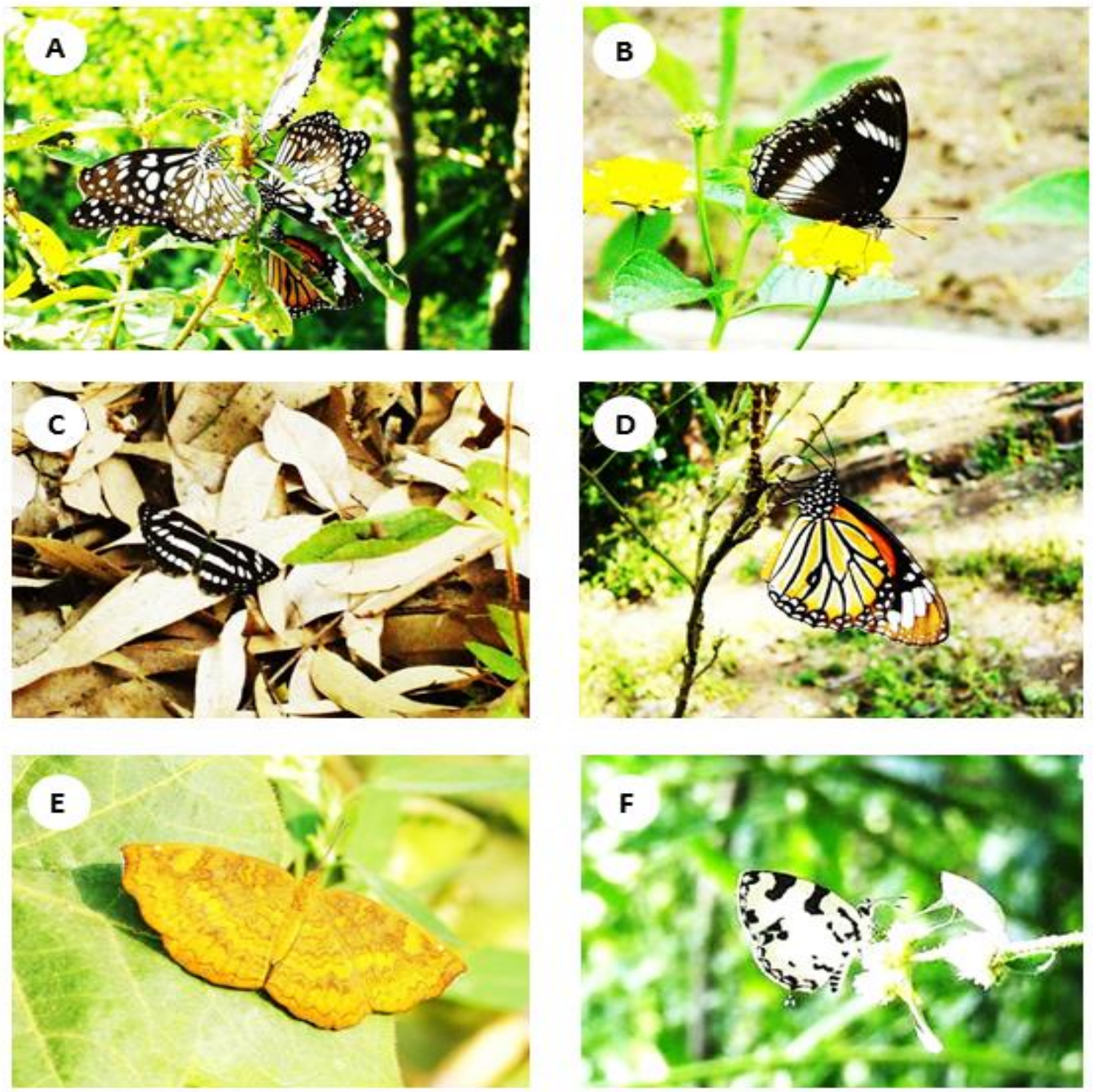

Fig. 3: Some of the Documented Butterfly Species from Waghai Botanical Garden, The Dangs, Gujarat, India (A) Group of Nymphalids Sucking Plant Sap (B) Great Eggfly Hypolimnas bolina Linnaeus, 1758 (C) Common Sailer Neptis hylas Linnaeus, 1758 (D) Stripped Tiger Danaus genutia Cramer, 1779 (E) Common Castor Ariadne merione Cramer, 1777 (F) Angled Pierrot Caleta decidia Hewitson, 1876. 


\subsection{Rendering Seasonal Diversity}

Table 5: Seasonal Distribution of Documented Species of Butterflies from Waghai Botanical Garden of The Dangs District

\begin{tabular}{|c|c|c|c|c|}
\hline Season & Month & No. of Species Observed & Maximum Average Temperature $\left({ }^{\circ} \mathrm{C}\right)$ & Average Monthly Rainfall (mm) \\
\hline \multirow{3}{*}{ Pre Monsoon } & Apr & 34 & 36 & 10 \\
\hline & May & 27 & 35 & 30 \\
\hline & Jun & 40 & 33 & 240 \\
\hline \multirow{3}{*}{ Monsoon } & Jul & 37 & 30 & 430 \\
\hline & Aug & 26 & 29 & 285 \\
\hline & Sep & 41 & 31 & 140 \\
\hline \multirow{2}{*}{ Post monsoon } & Oct & 55 & 34 & 60 \\
\hline & Nov & 63 & 32 & 15 \\
\hline \multirow{4}{*}{ Winter } & Dec & 48 & 30 & 0 \\
\hline & Jan & 36 & 28 & 30 \\
\hline & $\mathrm{Feb}$ & 30 & 31 & 0 \\
\hline & Mar & 45 & 34 & 10 \\
\hline
\end{tabular}

The Dangs form the northern most part of the Western Ghats region, which is considered to be one of the most diverse regions of India. The Dangs receives maximum rainfall in Gujarat. Seasonal distribution of butterfly species was also observed at Waghai Botanical Garden of The Dangs along with documentation of 70 species of butterflies. Monthly number of documented butterfly species observed with corresponding maximum average temperature and average monthly rainfall is provided in Table 5.

Along with the list, graphical representation of monthly distribution of documented butterfly species observed with respect to maximum average temperature and average monthly rainfall in Waghai is also depicted by $2 \mathrm{D}$ double $\mathrm{Y}$-axis plot in Figure 4 . Detailed seasonal occurrence of individual butterfly species within Waghai botanical garden is provided in Table 6 .

Table 6: Seasonal Distribution of Documented Species of Butterflies from Waghai Botanical Garden of The Dangs

\begin{tabular}{|c|c|c|c|c|c|c|}
\hline Sr.no & Family & Common Name & Scientific Name & $\begin{array}{c}\text { Pre } \\
\text { Monsoon }\end{array}$ & Monsoon & $\begin{array}{c}\text { Post } \\
\text { Monsoon }\end{array}$ \\
\hline 1 & \multirow{7}{*}{ Papilionidae } & \multirow{6}{*}{$\begin{array}{l}\text { Tailed Jay } \\
\text { Common Jay } \\
\text { Spot Swordtail } \\
\text { Common Rose } \\
\text { Crimson Rose } \\
\text { Lime Butterfly }\end{array}$} & \multirow{6}{*}{$\begin{array}{l}\text { Graphium agamemnon Linnaeus, } 1758 \\
\text { Graphium doson Felder \& Felder, } 1864 \\
\text { Graphium nomius Esper, } 1785 \\
\text { Pachliopta aristolochiae Fabricius, } 1775 \\
\text { Pachliopta hector Linnaeus, } 1758 \\
\text { Papilio demoleus Linnaeus, } 1758\end{array}$} & $\sqrt{ }$ & $\sqrt{ }$ & $\sqrt{ }$ \\
\hline 2 & & & & $\sqrt{ }$ & $\sqrt{ }$ & $\sqrt{ }$ \\
\hline 3 & & & & $\sqrt{ }$ & - & - \\
\hline 4 & & & & - & - & $\sqrt{ }$ \\
\hline 5 & & & & - & - & $\sqrt{ }$ \\
\hline 6 & & & & $\sqrt{ }$ & $\sqrt{ }$ & $\sqrt{ }$ \\
\hline 7 & & Common Mormon & Papilio polytes Linnaeus, 1758 & - & - & $\sqrt{ }$ \\
\hline 8 & \multirow{15}{*}{ Pieridae } & Western Striped Albatross & Appias libythea Fabricius, 1775 & $\sqrt{ }$ & - & $\sqrt{ }$ \\
\hline 9 & & Pioneer & Belenois aurota Fabricius, 1793 & $\sqrt{ }$ & $\sqrt{ }$ & $\sqrt{ }$ \\
\hline 10 & & Common Emigrant & Catopsilia pomona Fabricius, 1775 & $\sqrt{ }$ & $\sqrt{ }$ & $\sqrt{ }$ \\
\hline 11 & & Mottled Emigrant & Catopsilia pyranthe Linnaeus, 1758 & $\sqrt{ }$ & $\sqrt{ }$ & $\sqrt{ }$ \\
\hline 12 & & Common Gull & Cepora nerissa Fabricius, 1775 & $\sqrt{ }$ & - & $\sqrt{ }$ \\
\hline 13 & & Small Salmon Arab & Colotis amata Fabricius, 1775 & $\sqrt{ }$ & $\sqrt{ }$ & $\sqrt{ }$ \\
\hline 14 & & Crimson Tip & Colotis danae Fabricius, 1775 & - & - & $\sqrt{ }$ \\
\hline 15 & & Small Orange Tip & Colotis etrida Boisduval, 1836 & $\sqrt{ }$ & $\sqrt{ }$ & $\sqrt{ }$ \\
\hline 16 & & Common Jezebel & Delias eucharis Drury, 1773 & $\sqrt{ }$ & $\sqrt{ }$ & $\sqrt{ }$ \\
\hline 17 & & Small Grass Yellow & Eurema brigitta Stoll, 1780 & $\sqrt{ }$ & $\sqrt{ }$ & $\sqrt{ }$ \\
\hline 18 & & Common Grass Yellow & Eurema hecabe Linnaeus, 1758 & $\sqrt{ }$ & $\sqrt{ }$ & $\sqrt{ }$ \\
\hline 19 & & White Orange Tip & Ixias marianne Cramer, 1779 & $\sqrt{ }$ & $\sqrt{ }$ & $\sqrt{ }$ \\
\hline 20 & & Yellow Orange Tip & Ixias pyrene Linnaeus, 1764 & $\sqrt{ }$ & $\sqrt{ }$ & $\sqrt{ }$ \\
\hline 21 & & Psyche & Leptosia nina Fabricius, 1793 & $\sqrt{ }$ & - & $\sqrt{ }$ \\
\hline 22 & & Common Wanderer & Pareronia hippia Fabricius, 1787 & - & - & $\sqrt{ }$ \\
\hline 23 & \multirow{21}{*}{ Nymphalidae } & Tawny Coster & Acraea terpsicore Linnaeus, 1758 & $\sqrt{ }$ & $\sqrt{ }$ & $\sqrt{ }$ \\
\hline 24 & & Angled Castor & Ariadne ariadne Linnaeus, 1763 & $\sqrt{ }$ & $\sqrt{ }$ & $\sqrt{ }$ \\
\hline 25 & & Common Castor & Ariadne merione Cramer, 1777 & $\sqrt{ }$ & $\sqrt{ }$ & $\sqrt{ }$ \\
\hline 26 & & Common Nawab & Charaxes athamas Drury, 1770 & - & $\sqrt{ }$ & $\sqrt{ }$ \\
\hline 27 & & Black Rajah & Charaxes solon Fabricius, 1793 & $\sqrt{ }$ & - & $\sqrt{ }$ \\
\hline 28 & & Painted Lady & Vanessa cardui Linnaeus, 1758 & $\sqrt{ }$ & - & $\sqrt{ }$ \\
\hline 29 & & Plain Tiger & Danaus chrysippus Linnaeus, 1758 & $\sqrt{ }$ & $\sqrt{ }$ & $\sqrt{ }$ \\
\hline 30 & & Striped Tiger & Danaus genutia Cramer, 1779 & $\sqrt{ }$ & - & $\sqrt{ }$ \\
\hline 31 & & Common Indian Crow & Euploea core Cramer, 1780 & $\sqrt{ }$ & $\sqrt{ }$ & $\sqrt{ }$ \\
\hline 32 & & Common Baron & Euthalia aconthea Cramer, 1777 & $\sqrt{ }$ & - & - \\
\hline 33 & & Great Eggfly & Hypolimnas bolina Linnaeus, 1758 & $\sqrt{ }$ & - & $\sqrt{ }$ \\
\hline 34 & & Danaid Eggfly & Hypolimnas misippus Linnaeus, 1764 & - & $\sqrt{ }$ & $\sqrt{ }$ \\
\hline 35 & & Peacock Pansy & Junonia almana Linnaeus, 1758 & $\sqrt{ }$ & $\sqrt{ }$ & $\sqrt{ }$ \\
\hline 36 & & Grey Pansy & Junonia atlites Linnaeus, 1763 & - & - & $\sqrt{ }$ \\
\hline 37 & & Yellow Pansy & Junonia hierta Fabricius, 1798 & $\sqrt{ }$ & - & - \\
\hline 38 & & Chocolate Pansy & Junonia iphita Cramer, 1779 & $\sqrt{ }$ & - & $\sqrt{ }$ \\
\hline 39 & & Lemon Pansy & Junonia lemonias Linnaeus, 1758 & $\sqrt{ }$ & $\sqrt{ }$ & $\sqrt{ }$ \\
\hline 40 & & Blue Pansy & Junonia orithya Linnaeus, 1758 & $\sqrt{ }$ & - & - \\
\hline 41 & & Common Evening Brown & Melanitis leda Linnaeus, 1758 & $\sqrt{ }$ & - & $\sqrt{ }$ \\
\hline 42 & & Common Bushbrown & Mycalesis perseus Fabricius, 1775 & - & $\sqrt{ }$ & $\sqrt{ }$ \\
\hline 43 & & Common Sailer & Neptis hylas Linnaeus, 1758 & $\sqrt{ }$ & - & - \\
\hline
\end{tabular}




\begin{tabular}{|c|c|c|c|c|c|c|}
\hline Sr.no & Family & Common Name & Scientific Name & $\begin{array}{c}\text { Pre } \\
\text { Monsoon }\end{array}$ & Monsoon & $\begin{array}{c}\text { Post } \\
\text { Monsoon }\end{array}$ \\
\hline 44 & & Glassy Tiger & Parantica aglea Stoll, 1782 & - & - & $\sqrt{ }$ \\
\hline 45 & & Common Leopard & Phalanta phalantha Drury, 1773 & $\sqrt{ }$ & - & $\sqrt{ }$ \\
\hline 46 & & Baronet & Symphaedra nais Forster, 1771 & $\sqrt{ }$ & - & $\sqrt{ }$ \\
\hline 47 & & Blue Tiger & Tirumala limniace Cramer, 1775 & - & $\sqrt{ }$ & $\sqrt{ }$ \\
\hline 48 & & Common Five-ring & Ypthima baldus Fabricius, 1775 & $\sqrt{ }$ & - & $\sqrt{ }$ \\
\hline 49 & & Common Four-ring & Ypthima huebneri Kirby, 1871 & $\sqrt{ }$ & - & $\sqrt{ }$ \\
\hline 50 & \multirow{18}{*}{ Lycaenidae } & Plum Judy & Abisara echerius Stoll, 1790 & $\sqrt{ }$ & $\sqrt{ }$ & $\sqrt{ }$ \\
\hline 51 & & Angled Pierrot & Caleta decidia Hewitson, 1876 & - & $\sqrt{ }$ & $\sqrt{ }$ \\
\hline 52 & & Common Pierrot & Castalius rosimon Fabricius, 1775 & $\sqrt{ }$ & $\sqrt{ }$ & $\sqrt{ }$ \\
\hline 53 & & Forget-Me-Not & Catochrysops strabo Fabricius, 1793 & - & $\sqrt{ }$ & $\sqrt{ }$ \\
\hline 54 & & Lime Blue & Chilades lajus Stoll, 1780 & $\sqrt{ }$ & $\sqrt{ }$ & $\sqrt{ }$ \\
\hline 55 & & Plains Cupid & Chilades pandava Horsfield, 1829 & - & $\sqrt{ }$ & $\sqrt{ }$ \\
\hline 56 & & Angled Sunbeam & Curetis dentate Moore, 1879 & - & $\sqrt{ }$ & $\sqrt{ }$ \\
\hline 57 & & Indian Sunbeam & Curetis thetis Drury, 1773 & $\sqrt{ }$ & - & $\sqrt{ }$ \\
\hline 58 & & Gram Blue & Euchrysops cnejus Fabricius, 1798 & $\sqrt{ }$ & $\sqrt{ }$ & $\sqrt{ }$ \\
\hline 59 & & Indian Cupid & Everes lacturnus Godart, 1824 & $\sqrt{ }$ & $\sqrt{ }$ & $\sqrt{ }$ \\
\hline 60 & & Common Cerulean & Jamides celeno Cramer, 1775 & $\sqrt{ }$ & - & $\sqrt{ }$ \\
\hline 61 & & Zebra Blue & Leptotes plinius Fabricius, 1793 & $\sqrt{ }$ & $\sqrt{ }$ & $\sqrt{ }$ \\
\hline 62 & & Pale Grass Blue & Pseudozizeeria maha Kollar, 1848 & $\sqrt{ }$ & $\sqrt{ }$ & $\sqrt{ }$ \\
\hline 63 & & Red Pierrot & Talicada nyseus Guerin- Meneville, 1843 & $\sqrt{ }$ & $\sqrt{ }$ & $\sqrt{ }$ \\
\hline 64 & & Stripped Pierrot & Tarucus nara Kollar, 1848 & $\sqrt{ }$ & $\sqrt{ }$ & $\sqrt{ }$ \\
\hline 65 & & Dark Grass Blue & Zizeeria karsandra Moore, 1865 & $\sqrt{ }$ & $\sqrt{ }$ & $\sqrt{ }$ \\
\hline 66 & & Lesser Grass Blue & Zizina otis Fabricius, 1787 & $\sqrt{ }$ & $\sqrt{ }$ & $\sqrt{ }$ \\
\hline 67 & & Tiny Grass Blue & Zizula hylax Fabricius, 1775 & $\sqrt{ }$ & $\sqrt{ }$ & $\sqrt{ }$ \\
\hline 68 & \multirow{3}{*}{ Hesperiidae } & Brown Awl & Badamia exclamationis Fabricius, 1775 & - & $\sqrt{ }$ & $\sqrt{ }$ \\
\hline 69 & & Rice Swift & Borbo cinnara Wallace, 1866 & - & - & $\sqrt{ }$ \\
\hline 70 & & Dark Palm-Dart & Telicota bambusae Moore, 1878 & - & $\sqrt{ }$ & $\sqrt{ }$ \\
\hline
\end{tabular}

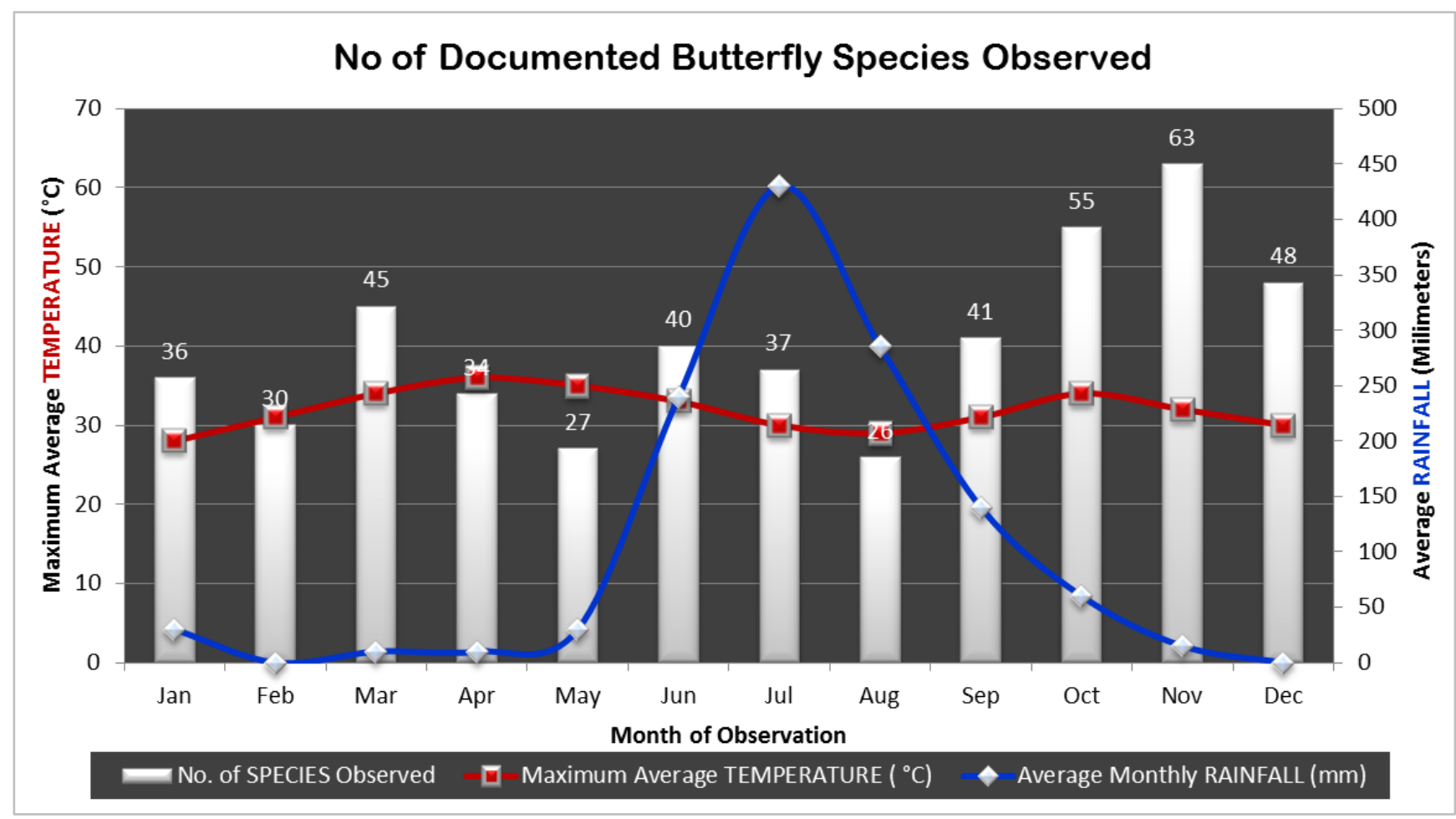

Fig. 4: Seasonal Distribution of Documented Species of Butterflies from Waghai Botanical Garden of The Dangs

In Botanical Garden of Waghai, average maximum temperature ranges from $33^{\circ} \mathrm{C}$ to $36^{\circ} \mathrm{C}$ in summer, which is best suitable for existence of butterflies; but as compared to other seasons, number of species observed during pre-monsoon months of April, May \& June in summer were comparatively less as compared to other seasons.

During monsoon season, very high total average rainfall of approx. $850 \mathrm{~mm}$ was observed in Waghai. This supports excellent quality and quantity of larval food plants for the caterpillars and nectar rich flower source for adults. Significant amount of rainfall makes the soil rich in nutrients $\&$ fertile for plants growth. Thus, as compared to all other seasons, highest numbers of butterfly species were observed in post monsoon months of October \& November i.e. 55 \& 63 species respectively.

Low visibility of butterfly species is mainly due to the heavy rainfalls and high humidity levels in the atmosphere. January being the coldest month of the year, also observed lower number of butterflies species due to sudden drop in temperatures.

Seasonal studies have also been conducted on papilionid butterflies in Assam of Northeast India and showed that rainfall and season showed variation in papilionid abundance and confirmed with the study that strong seasonality in observed in the South 
Asian butterfly assemblages (Barua et al., 2010). Team of researchers from Gauhati University conducted the seasonal studies of Nymphalidae butterflies in Rani Garbhanga Reserve Forest of Assam and observed total of 109 species of butterflies and combined it with the respective geographical distribution and seasonal abundance (Saikia et al., 2010).

Regarding other fragmented habitats, studies have also been conducted in various university campuses around India. Group of authors conducted the studies on the butterfly diversity in Manasagangotri campus of Mysore University and explored a total of 86 species of butterflies (Sarjan et al., 2014) and also observed large congregations of Catopsilia sp., Euploea core, Tirumala limniace, etc. during the study period.

Previously, studies on diversity of butterflies were carried out in fragmented habitats and have raised the voice of conservation of species along with its habitats. Duo authors from Singapore showed from their studies that the quantity of larval hosts plants and isolation form the forests are considered to the major determinants of butterfly richness in urban parks (Koh \& Sodhi, 2004) The authors also suggested that vegetation of such habitats with their larval host plants can elevate the conservation value of these butterflies.

\section{Conclusion}

In Habitat Preference study conducted within Waghai Botanical Garden, a total of 70 butterfly species belonging to 5 families were revealed mostly abundant within evergreen plots, medicinal plots $\&$ moist deciduous plots due to availability of food plants \& nectar resources. While, during Seasonal Diversity studies, highest numbers of butterfly species were found in post-monsoon season as compared to winter, pre-monsoon and monsoon season.

During post monsoon season in the month of October- November, temperature range varies between $32-34^{\circ} \mathrm{C}$ in Waghai, which is best suitable for existence of butterflies. Moreover high total average rainfall of around $850 \mathrm{~mm}$ in Waghai during monsoon provided excellent quality and superior quantity of larval food plants for the caterpillars as well as nectar rich flower source for adult butterflies in post-monsoon season. Thus from entire study, it can be concluded that apart from preferred habitat for butterflies, favourable temperature and adequate rainfall are the major life guarding factors for the existence of diverse butterfly species.

\section{Acknowledgement}

One of the authors, Suchi Gandhi is thankful to UGC-RFSMS fellowship scheme, New Delhi for the financial assistance to carry out the required study.

\section{References}

[1] Aldrich, HC, (1946). Butterflies of Kaira district - a list. Journal of Bombay Natural History Society, 46(2), pp.374- 377.

[2] Barua KK, Slowik J, Bobo KS., \& Muehlenberg M. (2010). Correlations of Rainfall and Forest Type with Papilionid Assemblages in Assam in Northeast India. Psyche, 1- 10. http://dx.doi.org/10.1155/2010/560396.

[3] Bhalodia K, Bhuva VJ, Dave SM \& Soni VC, (2002)a. Butterflies of Vansda National Park, Gujarat. Zoos' Print Journal, 17(10), pp.903- 904. http://dx.doi.org/10.11609/JoTT.ZPJ.17.10.903-4.

[4] Bhalodia K, Bhuva VJ, Dave SM \& Soni VC, (2002)b. Butterflies of Ratanmahal Wildlife Sanctuary,Gujarat. Zoos' Print Journal, 17(10), pp.905906. http://dx.doi.org/10.11609/JoTT.ZPJ.17.10.905-6.

[5] Bhalodia K, Bhuva VJ, Dave SM \& Soni VC, (2002)c. Butterflies of Narayansarovar Wildlife Sanctuary, Gujarat. Zoos' Print Journal 17(10), pp.906- 907. http://dx.doi.org/10.11609/JoTT.ZPJ.17.10.906-7.

[6] Evans, W. (1932). The Identification of Indian Butterflies (2nd Edition ed.). Bombay: The Bombay Natural History Society.
[7] Gandhi S \& Kumar D (2015) Studies on butterfly diversity, abundance and utilization of plant resources in urban localities of Banyan city- Vadodara, Gujarat, India. Journal of Entomology and Zoology Studies 3(4): 476-480.

[8] Gandhi S \& Kumar D (2015) Butterfly Species Abundance in Agricultural fields of Vadodara, Gujarat with Special Emphasis on the Conservation of Complementary Plantations. International Journal of Science and Research 4(10): 1933-1936.

[9] Kehimkar I. (2008). The Book of Indian Butterflies (1 ed.). (M. Gadgil, Ed.) Mumbai: Bombay Natural History Society.

[10] Koh LP, \& Sodhi NS (2004). Importance of Reserves, Fragments and Parks for Butterfly Conservation in a Tropical Urban Landscape. Ecological Applications, 14(6), 1695- 1708 http://dx.doi.org/10.1890/03-5269.

[11] Kunte K. (2000). India- A lifescape- Butterflies of Peninsular India. (M. Gadgil, Ed.) Hyderabad: Universities Press (India) Private Limited.

[12] Mali M, Khokhariya BP \& Dabgar YB (2014). Biotic Interrelationship of Plants and Butterflies in Surrounding of Gandhinagar, Gujarat. International Journal of Scientific Research, 3(4), pp.420 http://dx.doi.org/10.15373/22778179/APR2014/149.

[13] Mora C, Tittensor D, Adl S, Simpson A, \& Worm B (2011). How Many Species Are There on Earth and in the Ocean? PLoS Biol, 9(8), 1-8. http://dx.doi.org/10.1371/journal.pbio.1001127.

[14] Mosse AH, (1929). A note on the butterflies and hawkmoths of Kathiawar. Journal of Bombay Natural History Society, 33(3), pp.888- 892.

[15] Parasharya BM, \& Jani J (2007). Butterflies of Gujarat. Anand: Anand Agricultural University.

[16] Pollard E, Yates TJ (1993). Monitoring Butterflies for Ecology and Conservation. Chapman \& Hall, London, UK

[17] Saikia MK, Kalita J, \& Saikia PK. (2010). Seasonality of Nymphalid butterflies in Rani-Garbhanga Reserve Forest, Assam, India. NeBIO, 1(4), 10- 21.

[18] Sarjan, HN., Yangchan J, Kripa SK, Fatima S, Husna AA, \& Naik $P$ (2014). Butterfly diversity in Manasaganangotri campus of Mysore University. Zoos' Print, 29(8), 20- 25.

[19] Sharma A \& Ahmed SI (2013). Butterfly diversity in Dry Deciduous teak forests of Gir Protected Area, Gujarat, India. International Journal of Advanced Research, 1(7), pp.73- 82.

[20] Shull EM, (1963). The butterflies of South Gujarat. Journal of Bomaby Natural History Society, 60(3), pp.585- 599.

[21] Shull, EM (1964). Supplementary note on the butterflies of South Gujarat. Journal of Bombay Natural History Society, 61(2), pp.464466.

[22] Wynter Blyth MA (1957). Butterflies of the Indian Region. New Delhi: Today \& Tomorrow's Printers and Publishers. 